\title{
VAIKŲ LĖTINIS KOSULYS
}

DOC. DR. JOLANTA KUDZYTE்,

KMU VAIKU LIGŲ KLINIKA

Reikšminiai žodžiai: lètinis kosulys, vaikai.

Santrauka. Priimta laikyti, kad vaikų lètinis kosulys yra besitęsiantis ilgiau nei 4 savaites, o suaugusiuju - ilgiau nei 8 savaites. Tačiau Britų torakalistų draugijos (BTS) metodinèse rekomendacijose lètinis kosulys suskirstomas i smulkesnes grupes pagal kosulio pobūdį ir eigą. Straipsnyje pateikiami Europos respiratologų draugijos (ERS) ir BTS vaikų lètinio kosulio diagnostikos algoritmai. Nustačius lètinio kosulio kilmę, 80 proc. pacientų gydymas būna veiksmingas, todèl labai svarbu diagnozuoti kosulį sukèlusią ligą, o ne vartoti kosulį slopinančius vaistus.

Kosulys apsaugo žmogaus organizmą, pašalindamas skreplius, dirginamąsias medžiagas bei infekcijų sukèlejus iš kvèpavimo takų. Taigi kosulys ne visada reiškia, jog vaikas serga $[1,2,3,9]$.

Vaikų peršalimo ligos, kurių pagrindinis simptomas yra kelias savaites trunkantis kosulys, - dažniausia tèvų kreipimosi $\mathfrak{i}$ šeimos gydytojus priežastis. Kosuli vaikams gali sąlygoti daug ịvairių kvẻpavimo takų ligų, todèl labai svarbu surasti pagrindinę priežastị ir skirti reikiamą gydymą $[2,3,6]$.

Visuomenès apklausos duomenimis, tèvai labai dažnai skundžiasi tik izoliuotu simptomu - vaiko kosuliu. Kosulys nesant peršalimo būna 10 proc. ikimokyklinio ir jaunesnio mokyklinio amžiaus vaikų, 28 proc. berniuku ir 30 proc. mergaičių $[1,2,3]$.

Ūminị kosuli paprastai sukelia viršutinių kvėpavimo takų virusinè infekcija, o lètini - dažniau kitos būklès, kartais net labai sunkios. Vienintelè priežastis, kuri lemia lètinị kosulį, nustatoma 82 proc. vaikų, o apie 25 proc. kosinčių vaikų randamos dvi ar daugiau etiologinių priežasčių. Jei kosulio kilmé žinoma, gydymas būna efektyvus 84-97 proc. atvejų, todèl kosulio priežasčių reikia ieškoti, o ne vartoti kosuli slopinančius vaistus $[1,5]$.

Daugelis autorių vaikų lètiniu kosuliu vadina tokị, kuris tęsiasi ilgiau nei 4 savaites, o suaugusiųjų - ilgiau nei 8 savaites, o Brituc torakalistų draugijos metodinèse rekomendacijose lètinis kosulys suskirstytas ị keletą grupiu pagal kosulio pobūdị, eigą ir trukmę $[1,2,3,4,6,8]$.

Lètinis kosulys labai susijęs su aplinkos veiksniais (drègme namuose, oro tarša) bei socialine ekonomine padètimi. Jei šeimoje rūko abu tèvai, lètinio kosulio paplitimas tarp vaikų iki 11 metu išauga iki 50 proc. [5].

Kosulys vargina ne tik vaikus, bet ir visus šeimos narius, neleidžia vaikui išsimiegoti, sukelia problemų
1 lentelè. DAŽNIAUSIOS LĖTINIO KOSULIO PRIEŽASTYS (P. Y. CHOW, 2004)

Kūdikystè

1. Gastroezofaginis refliuksas

2. Infekcija

3. Igimtos sklaidos ydos

4. Igimtos širdies ydos

5. Pasyvus rūkymas

6. Aplinkos užterštumas

7. Astma

Vaikysté

1. Povirusinis kvejpavimo takų hiperreaktyvumas

2. Astma

3. Užnosinis varvèjimas

4. Pasyvus rūkymas

5. Gastroezofaginis refliuksas

6. Svetimkūnis kvepavimo takuose

7. Bronchektazès

Paauglystė

1. Astma

2. Užnosinis tekèjimas

3. Rūkymas

4. Plaučių tuberkuliozè

5. Bronchektazes

6. Psichogeninis kosulys

lankant darželị ar mokyklą, treniruotes, žaidžiant. Kosintis vaikas neleidžia išsimiegoti tèvams, trukdo mokytojams [7].

Naujausi tyrimai atskleidè, kad tèvai vaiko kosuli vertina kitaip nei gydytojai, todèl būtina išsami ligos anamnezè bei objektyvūs tyrimai [5].

Yra daug priežasčių, sąlygojančių lètinị kosulị, dažniausios jų - užnosinis varvejjimas, astma, gastroezofaginio refliukso liga, bronchektazès, tačiau mažesniems vaikams kosuli gali lemti igimtos sklaidos ydos, ikkvejpti svetimkūniai, ne mažiau svarbi aplinkos veiksnių ịtaka $[1,8]$. Dažniausios lètinio kosulio priežastys pateiktos eilès tvarka pagal dažnumą (1 lentelè) [1]. 
Ieškant galimos kosulio kilmès, labai svarbu išsiaiškinti buvusias problemas naujagimystès periodu, rijimo ar valgymo sutrikimus, atliktus skiepus, persirgtas infekcines ligas, buvusias alergines reakcijas ir alergines ligas šeimoje, artimuosius, sergančius tuberkulioze, lètines kvėpavimo taku ligas šeimoje, rūkymo ipročius, laikomus naminius gyvūnus. Labai svarbu ịvertinti vaiko fizinę raidą - svorị ir ūgị, nes sulètèjusio augimo priežastis gali būti sunki lètinè liga [2, 3].

ERS lètinio kosulio diagnostikos ir gydymo susitarime pateiktas vaiku lètinio kosulio tyrimo algoritmas matyti 1 paveiksle [2].

BTS vaiku kosulio diagnostikos ir gydymo metodinèse rekomendacijose siūloma vaikų kosulị pagal pobūdị, eigą ir trukmę skirstyti taip:

- Ūminis - iki 3 sav.

- Lètinis > 8 sav.

- Üminis užsitęsęs - 3-8 sav. (pvz., kokliušas, povirusinis kosulys).

- Pasikartojantis - kosulys neperšalus kartojasi du ar daugiau kartú per metus, trunka 7-14 d. Kai periodai dažni, sunku atskirti nuo lètinio kosulio.

- Povirusinis - kosulys po virusinès VKT infekcijos, trunkantis ilgiau nei 3 sav.

- Nespecifinis - nuolatinis sausas kosulys nesant kitu kvėpavimo takų sistemos simptomų, nèra pokyčių plaučių rentgenogramoje, fizinè raida neatsilikusi, vaikas atrodo sveikas.

- Specifinis - rasta priežastis, sukèlusi kosuli.

Rekomenduojama išsiaiškinti, ar kosulys sausas ar produktyvus ir drègnas, koks kosulio pobūdis: su reprizu būdingas kokliušui ar parakokliušui; staccato - mikoplazmos bei chlamidijos sukeltoms ligoms; "lojantis“ - laringitui, metalinis lyg „iš triūbos" - psichogeniniam kosuliui; su krauju - tuberkuliozei ir t. t., kas paskatina kosulį: fizinis krūvis, valgymas ir t. t., ar yra kitų kvėpavimo takų ligų simptomų [3].

Pastarųų metų moksliniai tyrimai, kuriuose naudota garso įrašų aparatūrą, ìrodè, jog sveikas (tuo metu nesergantis viršutinių kvejpavimo takų ligomis) vaikas sukosti 11 kartų per dieną, o kai kurie vaikai net 30 kartų. Kosulys padažnejja susirgus viršutinių kvėpavimo takų infekcinėmis ligomis. Kai kurie vaikai jomis serga 8-10 kartu per metus, ypač rudens, žiemos, pavasario sezonu. Kosulys paprastai tęsiasi ilgiau nei 7 dienas. Taigi kartais būna labai sunku, tačiau labai svarbu atskirti virusų sukeltą pasikartojantị kosulị "sveikai“ atrodančiam vaikui nuo sąlygoto sunkių lètinių ligų [3].

\section{Nerimą keliantys simptomai:}

- Pradžia naujagimysteje;

- Kosulys valgant;

- Staigi kosulio pradžia;

- Lètinis drègnas (produktyvus) kosulys, kai atkosima skreplių;

- Prakaitavimas naktimis;

- Svorio mažéjimas;

2008 / Nr. 2 (4)

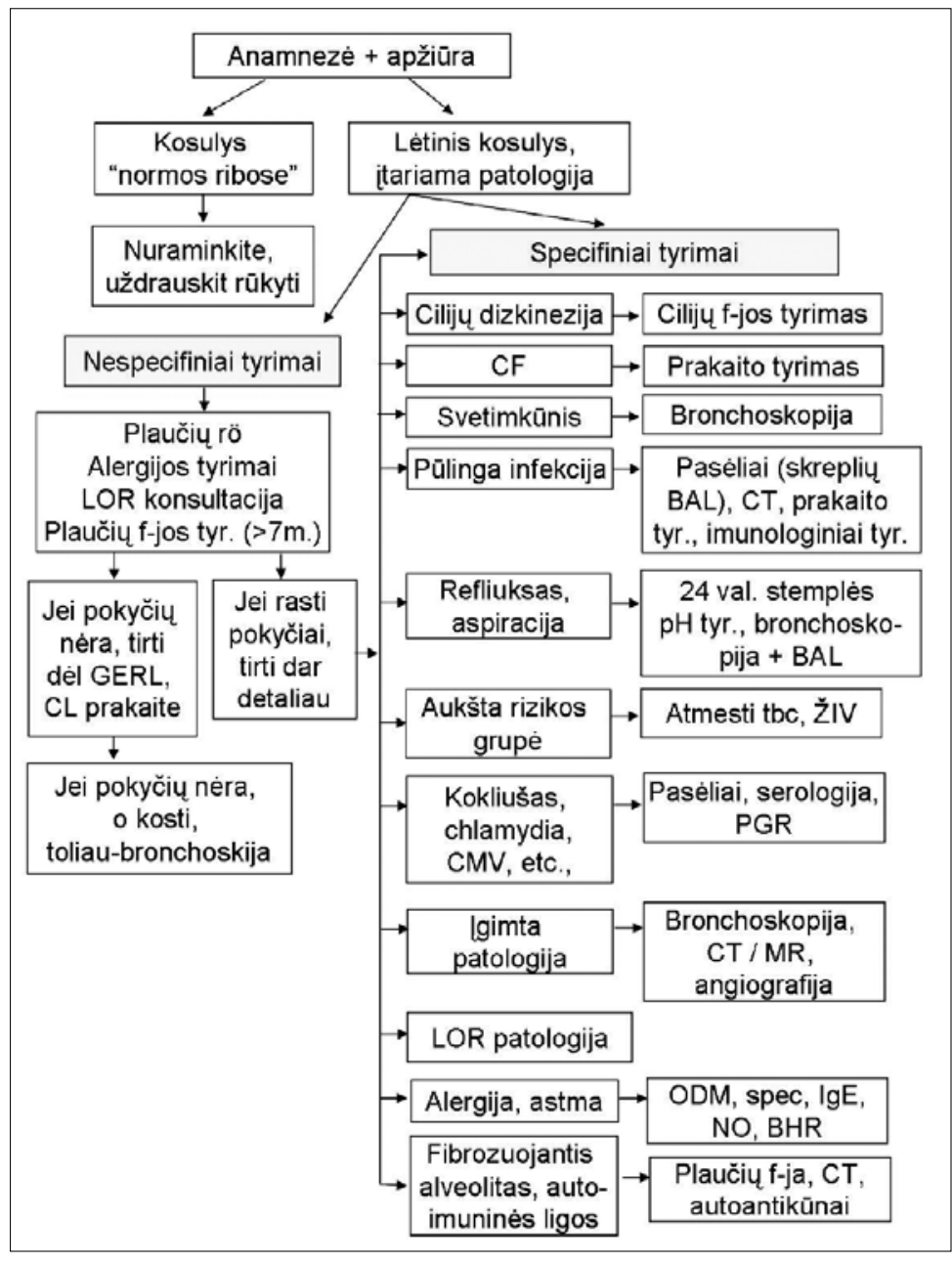

1 pav. LĖTINIO KOSULIO TYRIMO ALGORITMAS (A. H. MORICE IR KT.; EUR RESPIR J, 2004)

- Nesiliaujantis ar net ryškèjantis (blogejjantis) kosulys;

- Lètinių plaučių ligu simptomai.

Lètinio kosulio sèkmingą gydymą lemia teisinga diagnozè [2, 3]. Diagnozuoti padeda keletas paprastu ir iprastų tyrimo metodų:

- Detali, kruoščiai surinkta ligos ir gyvenimo anamnezė;

- Detalus klinikinis ištyrimas;

- Krūtinès ląstos rentgenografija;

- Kvèpavimo funkcijos tyrimas be bronchų hiperreaktyvumo tyrimo ar su juo, kai vaikas geba tai atlikti ( 6-7 m.);

- Skrepliu tyrimas;

- Alergijos tyrimas (odos dūrio méginiai ar specifiniai IgE);

- Jei reikia - bronchoskopija ir kompiuterinè tomografija.

Galimos „sveikai atrodančio“ vaiko kosulio priežastys ir tyrimai bei sunkių būklių tyrimai pateikti 2 ir 3 lentelèse. [3]

Taigi kosulys gali būti labai ịvairus, tačiau daugelis vaiku serga nesunkiai ar yra sveiki. Itarimas, kad kosintis vaikas serga sunkia lètine liga, kyla gerai surinkus anamnezę bei apžiūrèjus vaiką. Nuodugni vaiko apžiūra padiktuoja vaikų gydytojui specialistui tolesnę tyrimų seką. Pasinaudojus kosulio tyrimų algoritmu, kosulio etiologija nustatoma 80 proc. atveju ir jis veiks- 
2 lentelè. "SVEIKAI ATRODANČIO" VAIKO IZOLIUOTO KOSULIO PRIEŽASTYS

\begin{tabular}{|c|c|c|c|}
\hline Liga & Simptomai & Priežastys & Tyrimai \\
\hline $\begin{array}{l}\text { Pasikartojan- } \\
\text { tis virusinis } \\
\text { bronchitas }\end{array}$ & $\begin{array}{l}\text { Epizodinis, dažniau } \\
\text { žiemą, susijęs su } \\
\text { peršalimu }\end{array}$ & $\begin{array}{l}\text { Virusinè } \\
\text { infekcija. Vaikų } \\
\text { kolektyvų lanky- } \\
\text { mas. Gyvenimas } \\
\text { mažoje erdvèje. }\end{array}$ & $\begin{array}{l}\text { Krūtinès ląstos } \\
\text { rentgenograma. } \\
\text { Tirti vaiką, kai nèra } \\
\text { simptomų }\end{array}$ \\
\hline $\begin{array}{l}\text { Povirusinis } \\
\text { kosulys }\end{array}$ & $\begin{array}{l}\text { Kosulys dieną ir } \\
\text { naktị po virusinès } \\
\text { infekcijos ir lètai } \\
\text { nykstantis per } \\
2-3 \text { mèn. }\end{array}$ & $\begin{array}{l}\text { Virusinė infek- } \\
\text { cija, chlamidija, } \\
\text { mikoplazma }\end{array}$ & $\begin{array}{l}\text { Krūtinès ląstos } \\
\text { rentgenograma. } \\
\text { Serologiniai tyrimai. } \\
\text { Gydymas nuo astmos } \\
\text { ex juvantibus (gali } \\
\text { būti bronchų astma) }\end{array}$ \\
\hline $\begin{array}{l}\text { Kokliušas } \\
\text { I kokliušą pa- } \\
\text { našios ligos }\end{array}$ & $\begin{array}{l}\text { Spazminis kosulys, } \\
\text { retėjantis per } 3-6 \\
\text { mèn., reprizai, } \\
\text { vèmimas, dusulys }\end{array}$ & $\begin{array}{l}\text { B. Pertussis, } \\
\text { parapertussis, } \\
\text { adenovirusas, } \\
\text { influenza, } \\
\text { parainfluenza }\end{array}$ & $\begin{array}{l}\text { Krūtinès ląstos rent- } \\
\text { genograma. } \\
\text { Serologiniai tyrimai } \\
\text { Pasèliai }\end{array}$ \\
\hline $\begin{array}{l}\text { Kosulio } \\
\text { astma }\end{array}$ & $\begin{array}{l}\text { Izoliuotas kosulys be } \\
\text { švokštimo. Atopiné } \\
\text { anamnezė }\end{array}$ & Astma & $\begin{array}{l}\text { Krūtinès ląstos } \\
\text { rentgenograma. } \\
\text { Bronchų hiperrea- } \\
\text { ktyvumo, alergijos } \\
\text { tyrimai. Bronchos- } \\
\text { kopija. FeNO iškve- } \\
\text { piame ore. Atsakas i } \\
\text { gydymą nuo astmos }\end{array}$ \\
\hline $\begin{array}{l}\text { Alerginis rini- } \\
\text { tas, užnosinis } \\
\text { varvèjimas, } \\
\text { sinusitas }\end{array}$ & $\begin{array}{l}\text { Kosulys, kai „galva } \\
\text { paliečia pagalvę“. } \\
\text { Atkosejjimas, kai } \\
\text { „priteka ì gerklę“, } \\
\text { alerginis saliutas }\end{array}$ & Alerginis rinitas & $\begin{array}{l}\text { LOR konsultacija. } \\
\text { Alergijos tyrimai. } \\
\text { Krūtinès ląstos } \\
\text { rentgenograma, jei } \\
\text { reikia. Atsakas i } 2 \\
\text { sav. alerginio rinito } \\
\text { gydymą }\end{array}$ \\
\hline $\begin{array}{l}\text { Psichogeninis } \\
\text { kosulys }\end{array}$ & $\begin{array}{l}\text { Paauglystėje. Lieka } \\
\text { po peršalimo: ryškėja } \\
\text { streso sąlygomis, } \\
\text { nekosti miego metu } \\
\text { ar kai koncentruoja } \\
\text { dėmesị }\end{array}$ & & Atmesti kitas ligas \\
\hline
\end{tabular}

3 lentelè. SUNKIŲ BŪKLIŲ, KURIOMS BŪDINGAS LĖTINIS KOSULYS, TYRIMAS

\begin{tabular}{|c|c|}
\hline Liga & Tyrimai \\
\hline Cistinè fibrozè & $\begin{array}{l}\text { Prakaito tyrimas, nosies poten- } \\
\text { cialai, kasos funkcijos, genetiniai } \\
\text { tyrimai }\end{array}$ \\
\hline Imunodeficitas & Imunologiniai tyrimai \\
\hline Pirminė cilijų diskinezija & $\begin{array}{l}\text { FeNO, sacharino mėginys, cilijų } \\
\text { funkcijos tyrimas }\end{array}$ \\
\hline Užsitęsęs bakterinis bronchitas & $\begin{array}{l}\text { Krūtinès ląstos Rö, skreplių } \\
\text { pasèlis, bronchoskopija, HRCT, } \\
\text { atsakas i } 4-6 \text { sav. antibiotikų } \\
\text { kursą }\end{array}$ \\
\hline $\begin{array}{l}\text { Kartotinè aspiracija (vilko go- } \\
\text { murys, tracheoeozifaginè fistulè, } \\
\text { nervų-raumenų ligos, vaikų } \\
\text { cerebrinis paralyžius, gastroezo- } \\
\text { faginio refliukso liga ir kt.) }\end{array}$ & $\begin{array}{l}\text { Tyrimas su bariu, } 24 \text { val. } \\
\text { stemplès pH matavimas, pieno } \\
\text { izotopų skenavimas, riebalų } \\
\text { makrofagu indeksas, BAL, ezo- } \\
\text { fagoskopija }\end{array}$ \\
\hline Svetimkūnis kvėpavimo takuose & $\begin{array}{l}\text { Krūtinès ląstos Rö ir /ar CT, } \\
\text { bronchoskopija kietu bronchos- } \\
\text { kopu }\end{array}$ \\
\hline Tuberkuliozè & $\begin{array}{l}\text { Krūtinès ląstos Rö, Montoux } \\
\text { reakcija, rytinis skrandžio sulčiu } \\
\text { aspiratas }\end{array}$ \\
\hline Igimtos anomalijos & Bronchoskopija, CT \\
\hline Intersticinės plaučių ligos & $\begin{array}{l}\text { Spirometrija (restrikcija), krū- } \\
\text { tinès ląstos Rö, HRCT, plaučių } \\
\text { biopsija }\end{array}$ \\
\hline
\end{tabular}

mingas gydomas. Ketvirtadaliui ligonių kosuli sukelia keletas etiologinių priežasčių, todèl nesant efekto gydant vieną ligą, reikia ieškoti kitos galimos etiologinės priežasties ir gydyti. Pavyzdžiui, vaikai, sergantys astma, gali sirgti sinusitu ar gastroezofaginio refliukso liga, kas blogina astmos būklę ir dar patys sukelia lètini kosuli. Taigi, norint sèkmingai diagnozuoti ir gydyti vaikụ lètinị kosulì, būtinas keliụ subspecialybių vaikų gydytojų bendradarbiavimas $[1,4,5]$.

\section{CHRONIC COUGH IN CHILDREN}

\section{JOLANTA KUDZYTE \\ DEPARTMENT OF CHILDREN DISEASES \\ KAUNAS UNIVERSITY OF MEDICINE}

Key words: chronic cough, children.

Summary. Cough is a common symptom that brings a child to medical attention. Usually, chronic cough in children is defined as coughing for more than four weeks, but BTS recommendations for the assesment of cough in children give severel overlapping categories of chronic cough, defined with the help of good history and thorough physical examination. Diagnostic algorithms of chronic children cough are given in the article. A single cause can be found in up to 82 proc. of all cases of chronic cough and the majority of these can be suceessfully treated. Thus, it is imperative that one looks for the underlying cause and treat appropriately rather than use cough suppressants indiscriminately.

\section{LITERATŨRA}

1. PY Chow, D K K Ng. Chronic cough in children, Singapore Med. J 2004 Vo 45(10):462.

2. A.H.Morice at all. The diagnosis and management of chronic cough. Eur Respir J 2004; 24:481-492.

3. Michael D Shields, Andy Bush, Mark L Everard, Sheila A McKenzie and Rob Primhak. British Thoracic Society Guidelines Recommendations for the assessment and management of cough in children. Thorax published online 28 Sep 2007. doi:10.1136/thx.

4. Alyn H Morice, Andrew Bush. Cough. Current Medical Literature. 2003

5. Chronic Cough in Children. Baylor College of Medicine. www.bcm.edu/ cme_demo/courses/oto_01/content_01.html

6. Laurie Barclay. Evidence -Based Approach for Diagnosis, Treatment of Chronic Cough. www.medscape.com/viewarticle/555784

7. Bailey EJ, Morris PS, Kruske SG, Chang AB. Clinical pathways for chronic cough in children. www.cochrane.org/reviews/en/ab006595.html

8. Marchant JM, Masters IB, Taylor SM, et al. Chronic cough in children had various aetiologies and common causes of adult cough were found in $<10$ proc.of children. Chest 2006; 129:1132-41.

9. Tips to Remember: Cough in Children. Americal Academy of Allergy Asthma \& Immunology. www.aaaai.org/patient/punlicedmat/tips/ coughinchildren.stm 